\title{
Matter of S-E-G-: The Final Nail in the Coffin for Gang-Related Asylum Claims?
}

\author{
Lindsay M. Harris \& Morgan M. Weibel*
}

\author{
INTRODUCTION
}

In July 2008, the Board of Immigration Appeals (BIA) ${ }^{1}$ affirmed an Immigration Judge's ("IJ") denial of asylum to three young Salvadoran siblings fleeing gang violence and threats. This decision affects the likelihood that other youth and their family members fleeing gang violence will gain protection in the United States. The reach of the BIA decision in Matter of $S-E-G{ }^{2}$ stretches far beyond the facts of the actual case or gang cases in general and may shape the future of asylum based on membership in a particular social group. The BIA published Matter of $S-E-G$ - as one of only 36 precedent decisions in 2008 , making the decision binding on all IJs as well as the BIA itself. ${ }^{3}$ The decision is important, as it appears to elevate the notion of "social visibility" from a factor in the determination of a particular social group to a requirement. This article examines how Matter of $S-E-G-$ has affected the legal landscape with regard to asylum claims based on particular social group.

Part I of this paper provides a brief background on the Central American gang problem. Part II briefly examines the state of the U.S. law on social group prior to $S-E-G$-. Part III summarizes the decision itself, analyzes the problematic elements of the decision, and provides an update as to the current status of the case. Part IV examines U.S. case law following $S-E-G$ - in the Circuit Courts of Appeal. Part V presents an analysis of the potential impact of $S-E-G$ - on other social group cases. Part VI explores recent Canadian jurisprudence on gang-related persecution claims, while the conclusion suggests how advocates and judges can move past $S$ - $E$ - $G$ - to carefully consider gang-related cases.

\section{BaCkground on the Central American Gang Phenomenon}

Asylum seekers generally flee persecution from one of two Central

* Lindsay M. Harris, J.D. 2009, University of California, Berkeley, School of Law ("Berkeley Law"); Morgan M. Weibel, J.D. 2009, University of California, Hastings College of the Law. Thanks go to Professor Kate Jastram at Berkeley Law and Karen Musalo, Kim Thuy Seelinger and Lisa Frydman at the Center for Gender and Refugee Studies for their support. Lindsay Harris presented a version of this paper at the Centre for Refugee Studies Annual Student Conference, "Documenting the Undocumented: Redefining Refugee Status" at York University in Toronto, Canada, on April 16, 2009.

1. The Board of Immigration Appeals forms part of the official agency charged with enforcing the Immigration and Nationality Act under control of the Attorney General of the United States. Immigration and Nationality Act $\$ 243(\mathrm{~h}), 8$ U.S.C. 1253(h) (2009).

2. Matter of S-E-G-, 24 I. \& N. Dec. 579 (B.I.A. 2008).

3. See Board of Immigration Appeals Precedent Decisions, Volume 24, available at http://www.usdoj.gov/eoir/vll/intdec/nfvol24.htm (last visited Apr. 15, 2010). 
American gangs or "maras," the Mara Salvatrucha, also known as MS or MS-13, and the Mara 18. These gangs originated in the Salvadoran immigrant and refugee community in Los Angeles, California in the 1980s. ${ }^{5}$ In 1996, Congress expanded the list of offenses that constitute an "aggravated felony" and therefore grounds for removal, while simultaneously eliminating relief from removal for such crimes. ${ }^{6}$ As a result of these immigration reforms, the U.S. deported "more than 670,000 immigrants because of criminal convictions." Many of the deportees had spent most of their lives in the U.S., had few relatives remaining in their native lands, and sometimes even struggled to speak the local language. ${ }^{8}$ Affiliation with their former gangs for protection and support became a natural response and as a result, gangs flourished in El Salvador and expanded into neighboring Guatemala, Honduras, Mexico, and even Belize. ${ }^{9}$ In reaction to increasing gang-membership, many countries began to enact sweeping anti-gang legislation such as El Salvador's "Mano Dura" or "tough fist" law, which associates gang membership with tattoos and calls for the imprisonment of all tattooed individuals. ${ }^{10}$ Such legislation not only endangered civil liberties but also nearly doubled Latin American prison populations." Strapped for resources to begin with, the prisons became breeding grounds for gang violence, resulting in lethal riots and regular prison escapes. ${ }^{12}$ As gang-members return to their local communities they recruit and expand gang forces thus perpetuating the cycle of violence.

Today, asylum seekers fleeing gang-related persecution can be grouped into

4. The Central American gang phenomenon has been widely documented. See, e.g., Migration Policy Institute, Mary Helen Johnson, National Policies and the Rise of Transnational Gangs, April 2006, available at http://www.migrationinformation.org/Feature/display.cfm?id=394 (last visited Apr. 15, 2010); Jeffrey D. Corsetti, Marked for Death: The Maras of Central America and Those Who Flee Their Wrath, 20 GEO. IMMIGR. L.J. 407 (2006).

5. Ricardo Pollack, Gang life tempts Salvador teens (Jan 24, 2005) available at http://news.bbc.co.uk/2/hi/americas/4201183.stm; Daniel Schorn, The Fight Against MS-13: Dan Rather On Difficult Fight Against Dangerous Gang (Dec. 4, 2005) available at http://www.cbs news.com/stories/2005/12/01/60minutes/main1090941.shtml.

6. See Antiterrorism and Effective Death Penalty Act of 1996, Pub. L. No. 104-132, 110 Stat. 1214, and the Illegal Immigration Reform and Immigrant Responsibility Act of 1996, Pub. L. No. 104208, 110 Stat. 3009-546.

7. See Freddy Funes, Removal of Central American Gang Members: How Immigration Laws Fail to Reflect Global Reality, 63 U. MiAmI L. REV. 301, 307 (2008), (citing Deportees in Latin America and the Caribbean: Hearing Before the Subcomm. on the W. Hemisphere of the H. Comm. on Foreign Affairs, 110th Cong. 24-26 (2007) (testimony of Gary Mead, Assistant Director for Management, Office of Detention and Removal Operations, Bureau of U.S. Immigration and Customs Management, U.S. Department of Homeland Security). For a comprehensive summary of how U.S. deportation of convicted criminals or gang members has led to the gang problems in Central America that asylum seekers now flee. See id. at 301-14. See generally Harvard Law School, No Place to Hide: Gangs and Clandestine Violence in El Salvador (February 2007).

8. Juanita Darling, Inside Story: Mothers of the Banished; Over the Past Six Years, Thousands of Convicts Have Been Deported to El Salvador. Many of these Young Men Have Left Families Behind in Southern California. The Burden is Crushing. L.A. TIMES, November 21, 1999, at page 20.

9. Belize has historically been a safe haven for refugees fleeing Central American conflicts, but recently gang activity has been reported in Belize. Pre-emptive strike against MS-13 Gang in Belize, THE REPORTER (BELIZE) Nov. 2, 2007; Mara Presence in Belize, THE REPORTER (BELIZE) Nov. 9, 2007.

10. See Funes supra note 7 at 311 .

11. Id. at 312. Between 2000 and 2005 El Salvador's prison population doubled. Only seventeen months after enacting its law, Honduras had arrested over 1500 tattooed men.

12. See Funes supra note 7 at 314-15. 
two main categories: former gang members and persons fleeing gang recruitment. ${ }^{13}$ Although Immigration Judges and Courts of Appeal ${ }^{14}$ have sometimes treated persons fleeing gang recruitment more sympathetically than former gang members, both categories of individuals have generally been denied asylum thus far in the United States. ${ }^{15}$

\section{The NARrowing OF U.S. LAW ON PARTICUlar Social GrouP}

Although Matter of $S-E-G$ - has potentially wide-ranging ramifications for social group cases, the cases preceding $S-E-G$ - paved the way for this decision. U.S. jurisprudence on social group was framed by the 1985 BIA opinion in Matter of $A$ costa, which came only five years after the implementation of the Refugee Act. ${ }^{\text {to }}$ In Acosta, the Board held that a social group must be a "group of persons all of whom share a common, immutable characteristic," and that the common characteristic "must be one that the members of the group either cannot change, or should not be required to change because it is fundamental to their individual identities or consciences." 17

13. Other commentators have grouped those fleeing gang-persecution in different ways, particularly focusing on disaggregating the claims by gender. See Meghann Boyle, Paths to Protection: Ideas, Resources, and Strategies for Presenting Central American Gang-related Asylum Claims, 07-11 Immigr. Briefings 1 (2007) (categorizing claimants into four categories: male former gang members and male non-members, female former gang members and female non-members); Matthew J. Lister, GangRelated Asylum Claims: An Overview and Prescription, 38 U. MEM. L. REV 827 (2008) (categorizing claimants as female applicants fleeing rape, trafficking, or violence from a gang, male applicants with no former gang ties, and male former gang members); Melissa James, Fleeing the Maras: Child Gang Members Seeking Refugee Status in the United States, 25 CHILD. LEGAL RTS. J. 3 (2005) (focusing on child gang members fleeing gang persecution); Michele A. Voss, Young and Marked for Death: Expanding the Definition of "Particular Social Group" in Asylum Law to Include Youth Victims of Gang Persecution, 37 RUTGERS L.J. 235, 263-274 (2005) (analyzing gang claims in two categories - "former gang members" and "youth recruited by gangs, or otherwise targeted by gangs").

14. Briefly, the U.S. asylum system has two modes of applying for asylum. Applicants can submit an affirmative application at an asylum office. An asylum officer may grant asylum or refer the case to an immigration court. The Immigration Courts are located within the Department of Justice's Executive Office of Immigration Review. Asylum applications before the Immigration Court are either referred cases from the asylum office, or defensive asylum applications submitted when the individual is placed into removal proceedings. If the case is denied, the applicant appeals to the BIA, also housed under the Department of Justice. An applicant can appeal from a BIA denial to one of the eleven U.S. federal circuit Courts of Appeal. From there, there is a final, but rare, possibility of an appeal to the United States Supreme Court if the court grants certiorari.

15. See, e.g., Arteaga v. Mukasey, 511 F. 3d 940 (9th Cir. 2007); Castellano-Chacon v. INS, 341 F. 3d 533 (6th Cir. 2003). For detailed discussion of the pre-S-E-G-case law involving gang-related persecution claims, see Lister, supra note 13; Boyle, supra note 13 (discussing a number of Immigration Judge decisions in the Center for Gender and Refugee Studies database relating to gang persecution); see Voss, supra note 13 (discussing gang-related asylum cases from 2005 and earlier).

16. Matter of Acosta, 19 I. \& N. Dec. 211 (B.I.A. 1985) (rejecting social group of taxi drivers in El Salvador who were members of a taxi cooperative targeted by guerillas).

17. Id. at 233. See Fatma E. Marouf, The Emerging Importance of "Social Visibility" in Defining a "Particular Social Group" and Its Potential Impact on Asylum Claims Related to Sexual Orientation and Gender. 27 YALE L. \& POL'Y REV. 47, 51-58 (2008), discussing the Acosta approach. In arriving at the immutable characteristic standard the BIA, first considered a "purely linguistic analysis" of the social group ground, commenting that it may encompass groups of individuals of "certain relation" such as coming from a "like class" or maintaining "kindred interests, such as shared ethnic, cultural, or linguistic origins, education, family background, or perhaps economic activity." Ultimately, the BIA applied the doctrine of ejusdem generis, "of the same kind" in construing the phrase in relation to the other enumerated grounds. The BIA reasoned that, because the other grounds, including race, religion, political 
More than two decades later, the BIA first articulated the notion of social visibility in Matter of $C-A-{ }^{18}$ Although the BIA claimed that it continued to "adhere to the Acosta formulation," never addressed. ${ }^{20}$ In Matter of $C-A$-, the BIA agreed with the IJ's rejection of the social group of "confidential informants against the Cali [drug] cartel," in part due to a lack of societal recognition of such a social group. ${ }^{21}$ The BIA elaborated on the concept of "social visibility" in Matter of $A-M-E-\& J-G-U_{-}^{22}$ finding that the proposed group of "wealthy Guatemalans" was not readily identifiable because "violence and crime in Guatemala appear to be pervasive at all socio-economic levels." ${ }^{23} A-M-E$ - also re-emphasized a need for "particularity," which, in addition to "social visibility," was not considered in the Acosta decision that had shaped U.S. asylum law for more than twenty years.

\section{The BoARd of IMmigration Appeals Decision IN MATTER OF $S-E-G_{-}{ }^{24}$}

Matter of $S-E-G$ - involved two Salvadoran teenage brothers who were approached by MS-13 gang members and encouraged to join. ${ }^{25}$ Although the brothers were beaten and threatened, they did not report the attack to the police because they feared retaliation and did not believe that the police would help. ${ }^{26}$ The gang also threatened to rape the brothers' older sister if they did not join. After another boy in their neighborhood was killed for refusing to join, all three siblings

opinion, and nationality, are based upon an immutable characteristic, the social group ground should likewise form its basis upon such a characteristic in order to be "comparable to the other four grounds of persecution under the Act." Id. at 219,233. See, e.g., ATLE GraHL-MADSEN, THE STATUS Of RefugEeS IN INTERNATIONAL LAW 219 (1966). We should note that the Ninth Circuit developed another formulation for social group, which requires a group to be united by a "voluntary association." SanchezTrujillo v. INS, 801 F.2d 1571, 1574-75 (9th Cir. 1986).

18. The BIA themselves claim that social visibility has been present in their decision-making for much longer. The concept was first referred to as "social visibility" in 2006 . In re C-A-, 231 . \& N. Dec. 951 (B.I.A. 2006), aff d, Castillo-Arias v. United States AG, 46 F.3d 1190 (11th Cir. 2006), cert denied sub nom. Castillo-Arias v. Gonzales, 549 U.S. 1115 (2007). For an extensive discussion of social visibility see Marouf, supra note 17.

19. Matter of Acosta, 23 I. \& N. Dec. 211 (BIA 1985).

20. In re C-A- 23 I. \& N. Dec. 951, 957 ("The Eleventh Circuit has directed us to consider whether 'non-criminal informants' are a particular social group in the context of this case. We find that this group is too loosely defined to meet the requirement of particularity.").

21. Id. at 953 .

22. In re A-M-E- \& J-G-U-, 24 I. \& N. Dec. 69 (B.I.A. 2007) aff'd, Ucleo-Gomez v. Mukasey, 509 F. 3d 70 (2d Cir. 2007). See also "Second Circuit Upholds BIA Decision that "Affluent Guatemalans" Do Not Constitute a Particular Social Group," 84 Interpreter Releases 2874 (Dec. 10, 2007).

23. A-M-E- and J-G-U-, 24 I. \& N. Dec. 69 (BIA 2007); see also, 84 No. 41 Interpreter Releases 2461. But see Romero v. Mukasey, 2008 WL 268682 (2d Cir. 2008) (unpublished) (finding social group of wealthy landowners and businessmen to be acceptable as it was not defined solely by wealth).

24. A companion case to $S-E-G-$, Matter of $E-A-G$-, was also published on July $30,2008$. Matter of E-A-G-, 24 I. \& N. Dec. 591 (July 30, 2008) (holding that "persons resistant to gang membership" were not socially visible in Honduras, and that membership in a particular social group of "Young persons who are perceived to be affiliated with gangs" was not a social group because actual membership in a criminal gang is not a social group). We focus on $S-E-G$-here as it is a longer opinion and $E-A-G$ - specifically refers the reader to $S-E-G$ - for additional detail of the evolving case law on particular social group. $I d$. at 6 .

25. Matter of S-E-G-, 24 I. \& N. Dec. 579

26. Id. at 2 
(the "Miras") fled El Salvador and sought asylum in the United States. ${ }^{27}$

In a decision by Board Member Grant, the BIA affirmed an IJ's denial of asylum to the three Salvadoran youths, Pablo, Silvia, and Rene Mira. Although the IJ found the siblings credible, the IJ found that (1) the Miras had not suffered past persecution; (2) they had not established nexus either to membership in a particular social group or to a political opinion; and (3) that the attack and threats occurred because the gang wanted to recruit new members. ${ }^{28}$ Further, the IJ held that the Salvadoran government's efforts to control gangs disproved the Miras' contention that the government was unwilling or unable to control gangs within its jurisdiction. 29

The BIA affirmed the IJ's rejection of the Mira siblings' asylum claims based on a well-founded fear of persecution on account of 1) their anti-gang political opinion; 2) their social group of "Salvadoran youth who have been subjected to recruitment efforts by MS-13 and who have rejected or resisted membership in the gang based on their own personal, moral and religious opposition to the gang's values and activities;" and 3) their social group of family members of such Salvadoran youth. ${ }^{30}$

\section{A. The BIA Found that an Anti-Gang Opinion is Not a Political Opinion}

With regard to political opinion, the BIA found that the Miras did not show that they had a "political motive in resisting gang recruitment or a well-founded fear of future persecution on account of their political opinion." ${ }^{31}$ The BIA found the evidence in the record insufficient to show that the Miras were "politically active or made anti-gang political statements." 32 This reasoning suggests that only those who put themselves in more danger, by openly criticizing dangerous gangs, will be eligible for asylum based on their political opinion. The BIA did not address the argument that refusal to join the gang demonstrates a political opinion. ${ }^{33}$ Ultimately, even if victims of gang persecution organized to become politically active and outspoken against gangs, a claim based on political opinion would still be denied under $S-E-G$ because the BIA refused to equate anti-gang opinion with political opinion. Although $S-E-G$ - itself did not present the strongest facts regarding political opinion, courts have denied claims even in cases where the individuals have engaged in more openly visible political activities. These decisions appear to overlook the practical realities of gangs, while at least one expert on Salvadoran gangs has gone so far as to say that the gangs themselves are political entities. ${ }^{34}$ Gangs, through

27. For a more detailed presentation of the facts, see Anne Marie Gallagher, Refugees and Asylees; Temporary Protected Status (TPS). 2 Immigration Law Service 2d \$10:164 (2009); Neither Youths Who Resist Gang Recruitment Nor Their Families Are a "Particular Social Group," BIA Finds, 85 No. 30 Interpreter Releases 2104 (2008). Alternatively, the decision itself summarizes the facts. See Matter of S-E-G, 24 I. \& N. Dec. 579 at 1-5.

28. Matter of S-E-G-, 24 I. \& N. Dec. 579, 581 (B.I.A. 2008). The IJ's decision itself is not publicly available. A number of other commentators have summarized Matter of $S-E-G$-. See Gallagher, supra note 27; Interpreter Releases supra note 16; see also Funes, supra note 7 at 326-28.

29. $I d$. at 5 .

30. Id. at $5-6$.

31. Id. at 22

32. $I d$.

33. Id. at 24-25.

34. See Max Manwaring, Street Gangs: The New Urban Insurgency, Strategic Studies 
their illegal actions, can be assumed to be anti-government and against the rule of law. It seems logical to therefore conclude that those who oppose the gangs may do so for political opinions, based on strong moral or religious beliefs in the rule of law and faith in the government.

\section{B. The BIA Found the Mira Siblings' Particular Social Group to Lack Particularity and Social Visibility.}

The BIA found the proposed social group of "Salvadoran youth ... who have rejected or resisted membership in the gang based on their own personal, moral, and religious opposition to the gang's values and activities" to be problematic on a number of levels. ${ }^{35}$ First, the BIA said that while youth is a mutable characteristic (evidenced by the fact that respondents are no longer "children"), "age is not within one's control" and as such, social group claims based on age "may still be cognizable." ${ }^{36}$ Further, the Board stated the well-established principle that a social group cannot be defined "exclusively by the fact that its members have been subjected to harm in the past." 37 This reasoning ignores, however, the other aspects of the proposed social group in $S-E-G-$, including moral and religious beliefs and is inconsistent with established precedent. ${ }^{38}$ Moral and religious beliefs are undoubtedly the kind of fundamental characteristic that an individual should not be required to change in order to avoid persecution. ${ }^{39}$ Therefore, under Acosta, the Miras' proposed social group should be valid.

The BIA then discussed its recent decisions, "holding that membership in a purported social group requires that the group have particular and well-defined boundaries, and that it possesses a recognized level of social visibility." 40 The BIA asserted that particularity and social visibility "give specificity to the definition of a social group." In addressing particularity, the BIA found that the Miras' social group did not meet the "particularity requirement of the refugee definition." BIA reasoned that the proposed social group represents "a potentially large and diffuse segment of society" and concluded that the Mira Siblings were "therefore not in a substantially different situation from anyone who has crossed the gang, or who is perceived to be a threat to the gang's interest."

Institute, U.S. Army War College (March 2005) 12-15, available at http://www.strategicstudiesinstitute. army.mil/pubs/display.cfm?publD=597 (describing Central American gangs as political entities, rather than merely criminal entities) (last visited Apr. 15, 2010).

35. Matter of S-E-G-, 24 I. \& N. Dec. 579,581 (B.I.A. 2008).

36. Id. at 583-84. The Third Circuit took a similar position in Lukwago v. Aschroft, 329 F. $3 \mathrm{~d}$ 157, 170-73 (3d Cir. 2003) (finding that while "children from Northern Uganda who are abducted and enslaved" by a guerilla organization are not part of a social group under a past persecution analysis, "children who have escaped from involuntary servitude after being abducted and enslaved" by the same entity have a social group claim for future persecution).

37. Id. at 12 .

38. See Brief for The Center for Gender and Refugee Studies as Amici Curiae, in support of Petitioner's Petition for Rehearing and Rehearing en banc. Santos-Lemus v. Mukasey, 542 F.3d 738 (9th Cir. 2008).

39. See Matter of Acosta, 19 I. \& N. Dec. 211 (B.I.A. 1985).

40. Matter of S-E-G-, 24 I. \& N. Dec. 579,582 (B.I.A. 2008).

41. Id.

42. Id. at 585 (emphasis added)

43. $I d$.

44. Id. at 587 (finding that "[i]t is difficult to conclude that any 'group' is actually perceived 
Although the Mira brothers defined their social group with more particularity than many other social groups found valid in the past, the BIA nonetheless found a lack of particularity. The brothers asserted that their group was defined more specifically as "male children who lack stable families and meaningful adult protection, who are from middle and low income classes and live in territories controlled by the MS-13 gang, and who refuse recruitment." ${ }^{45}$ The BIA found a lack of particularity for two reasons. First, the BIA said that the characteristics were amorphous because "people's ideas of what terms mean can vary." 46 Second, the BIA found no evidence in the record showing that gang members limit recruitment efforts to the specified social group. ${ }^{47}$ The first rationale for a lack of particularity seems to involve social visibility in the particularity analysis - asking what other "people," presumably members of Salvadoran society, would interpret the asserted group characteristics to mean. Because society's views on what certain terms mean will always vary, this means that the particularity requirement will never be met. ${ }^{48}$ The second rationale seems irrelevant - the fact that a persecutor persecutes a second group should not undermine the particularity of the first group.

The BIA is unclear as to whether social visibility is a factor or a requirement in the social group determination. In one sentence, the BIA explains, "we have recently reaffirmed the importance of social visibility as a factor in the particular social group definition." 49 Just one sentence later, the BIA "reaffirm[ed] the requirement that the shared characteristic of the group should be recognizable by others in the community." Nations High Commissioner for Refugees' (UNHCR) 2002 social group guidelines "endorse an approach in which an important factor is whether the members of the

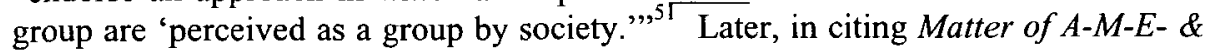
$J_{-} G_{-} U_{-}$, the Board referred to social visibility as "requisite," suggesting once again that social visibility is required for all social groups. ${ }^{52}$ Unlike Matter of $C-A-$, where social visibility was treated as a "relevant factor," that the proposed social group "fails the "social visibility' test." on whether social visibility is a factor or a requirement indicates a lack of consistency, so under Chevron, ${ }^{55}$ Circuit courts should not afford the BIA deference

by the criminal gangs, is much narrower than the general population of El Salvador").

45. Id. at 585 .

46. Id. (internal citation omitted).

47. Id.

48. See Marouf, supra note 17 at 71 discussing the inherent difficulty in assessing society's perception in the country origin.

49. Matter of $S-E-G-, 241 \&$ N. Dec. at 17 (emphasis added).

50. Id. at 18 (emphasis added).

51. Id. (emphasis added).

52. Id. at 19 .

53. The Harvard Immigration and Refugee Clinic (HIRC) and the Central American Resource Center (CARECEN) noted this inconsistency in their amicus brief for a later Ninth Circuit case. Brief for Harvard Immigration and Refugee Clinic and Central American Resource Center as Amici Curiae in support of petitioner's petition for rehearing and rehearing en banc in Santos-Lemus v. Mukasey, 542 F.3d 738 (9th Cir. 2008), see Section V(d)'s Discussion of Ninth Circuit jurisprudence for more information on the Santos-Lemus case.

54. Matter of $S-E-G-, 24$ I. \& N. Dec. at 22.

55. Briefly, the particular social group category has often been classified as the "least welldefined on its face" of the INA's five protected grounds leading courts to afford great Chevron deference 
in this inconsistent approach. ${ }^{56}$

The BIA did not address the government's willingness or ability to control the gang, because they found the respondent's failure to demonstrate a nexus to a protected ground dispositive. ${ }^{57}$

\section{Current Developments in Matter of S-E-G-}

On February 23, 2009, while on appeal at the Eighth Circuit, the attorneys in Matter of $S-E-G$ - sent a request to Attorney General Eric Holder for certification. On July 28, 2009, the BIA reopened the case at the request of a joint motion filed by the Miras and the Department of Homeland Security (DHS). ${ }^{59}$ The Miras filed motions to reopen and reconsider with the BIA, submitted requests for certification of Matter of $S-E-G$ - to Attorney General Holder, and pursued a petition for review at the U.S. Court of Appeals for the Eighth Circuit. ${ }^{60}$ The BIA denied the motion to reopen in June 2009 while the Eighth Circuit appeal and request for certification remained pending.

On July 6, 2009, Immigration and Customs Enforcement (ICE) agents unexpectedly arrested and detained the Miras and set their removal for the last week of July. ${ }^{62}$ ICE summarily denied the Miras' requests for an administrative stay and the Eighth Circuit denied a judicial stay. ${ }^{63}$ The Miras then filed an emergency application for a stay of removal with Supreme Court Justice Alito. ${ }^{64}$ He denied the application and the respondents refiled with Justice Stevens who referred the matter to the full court. ${ }^{65}$ When the full court requested the government's response by July 29,2009 , ICE released the respondents. ${ }^{66}$ DHS's appellate counsel and the Solicitor

to BIA interpretations. Koudriachova v. Gonzales, 490 F.3d 255, 260 (2d Cir. 2007). The principle of agency deference was first established by the Supreme Court in Chevron U. S.A. Inc. v. Natural Resources Defense Council, Inc, 467 U.S. 837 (1984). The test derived from Chevron is two pronged; first, a court determines whether or not "Congress has directly spoken to the precise question at issue" and second, if Congressional intent is not clear, then a court considers "whether the agency's answer is based on a permissible construction of the statute." Id. at 842-43.

56. In their Santos-Lemus briefs HIRC and CARECEN argue that the Ninth Circuit should have remanded to the agency to decide whether social visibility is a factor or a requirement. In the alternative, the Court should not give the social visibility requirement deference as the BIA departed from its former precedent, treating social visibility as only a factor, in a "sudden and unexplained" manner. HIRC \& CARACEN amicus, supra note 53 at 14, citing Brand $X$.

57. Matter of $S-E-G-, 24$ I. \& N. Dec. at 26.

58. Bress, Mallen, Alvino-McGill, Stuhlman, and Casper, Request for Attorney General Certification of Matter of S-E-G Feb. 23, 2009 available at:/www.immigrantlawcentermn.org/Litigation/ Resources/SEG-AG_Certification_request_final.pdf (last visited Apr. 15, 2010); see also Joe Palazzolo, Holder Asked to Review Asylum Decision, Legal Times, March 02, 2009, available at http://www.law.com/jsp/dc/Pub ArticleDC.jsp?id=1202428585096\&hub=TopStories (last visited Apr. 15, 2010).

59. John Keller, "BIA reopens, remands Matter of S-E-G-, ID 3617, 24 I\&N Dec. 579 (BIA 2008)" (July 28, 2009), available at http://drop.io/uobx4ey (last visited Apr. 15, 2010).

60. See Palazzolo supra note 58.

61. See Keller supra note 59.

62. Id.

63. Id.

64. Id.

65. Id.

66. Id. 
General's office then contacted respondents and offered a joint motion to reopen. ${ }^{67}$

The two Mira brothers were found eligible to reapply despite the fact that both are now over the age of eighteen because both were under the age of eighteen when they first filed for asylum. ${ }^{68}$ Although the William Wilburforce Trafficking Victims Protection and Reauthorization Act of 2008 does not cover the Miras' older sister, the BIA reopened her case alongside the others because all three siblings present the "same underlying claim" and reopening will "facilitate having that claim adjudicated in a consistent manner." ${ }^{, 69}$ As of January 2010, all three cases remain pending at the asylum office. While the Miras may eventually be granted relief, the decision itself remains in effect. As the $S-E-G$ - attorneys argued in their requests for certification, the BIA's decision has wide-ranging implications for asylum law, and may still render social visibility a requirement in all future social group cases.

UNHCR maintains that the BIA misconstrued the UNHCR Social Group Guidelines. "Under the Guidelines, the "social perception" approach should only be invoked if the requirement of a "protected characteristic"-a common immutable characteristic-is not met. ${ }^{72}$ UNHCR explains that "the second inquiry is an alternative to be considered if and only if a determination is made that the group characteristic is neither immutable nor fundamental." "73 UNHCR focuses on the "social perception" analysis, explaining that there is no requirement that the "common attribute [be] visible to the naked eye in a literal sense of the term or that it be one that is easily recognizable to the general public." ${ }^{74}$ Instead, the UNHCR approach to social group determination rests on whether a group is 'cognizable' or 'set apart from society at large' in some way." "The UNHCR social perception approach does not require group members to be individually recognized by the general public, but just for the group as a whole to be recognized in society. UNHCR notes the absence of a "social visibility" or "social perception" requirement in Acosta and other fundamental U.S. social group cases.

67. Id.

68. The Miras'eligibility was found pursuant to the William Wilburforce Trafficking Victims Protection and Reauthorization Act of 2008. Joint Motion of U.S. Department of Homeland Security and Respondents to Reopen Proceedings, Matter of $S-E-G-$, (July 23, 2009), available at http://drop.io/uobx4ey (last visited Apr. 15, 2010).

69. Id.

70. Request for Attorney General Certification of Matter of S-E-G, supra note 58 at 5.

71. Thomas Albrecht, UNHCR, Letter to Attorney General Holder Requesting Certification and Review of Matter of S-E-G-, March 18, 2009 (on file with author) [hereinafter "UNHCR letter"], citing UNHCR Guidelines on International Protection: "Membership of a Particular Social Group" HCR/GIP/02/02 (May 7, 2002). See also Brief for the UNHCR as Amicus Curaie Supporting Claimants in Thomas at 8, available at: http://www.unher.org/refworld/country,,,AMICUS,ZAF,456d62 le2,45c3 $4 \mathrm{c} 244,0 \mathrm{html}$ ("members of a group need not be easily recognizable to the general public in order for the group as a whole to be perceived by society as a particular social group.").

72. UNHCR letter, supra note 71 at 3.

73. Id. (emphasis added).

74. Id.

75. Id.

76. Id. at 4, citing Matter of Kasinga, 21 I. \& N. Dec. 357 (BIA 1996); Matter of Fuentes, 19 I. \& N. Dec. 658 (BIA 1988); Matter of Toboso-Alfonso, 20 I. \& N. Dec. 819 (BIA 1990). 


\section{Matter of $S$-E-G-AfFects Social Group CaSes ACross the Circuits.}

In the year following the decision, ten of the eleven U.S. Circuit Courts of Appeal cited Matter of $S-E-G$-, although the Third, Fourth, and Fifth Circuits did not publish any of their decisions on the matter. ${ }^{77}$ These cases involve both gang-related claims and non-gang related claims, but in all cases asylum was denied. We first address the cases involving gangs. In considering these claims, three circuits, the Sixth, Ninth, and Eleventh seem to have adopted social visibility as a requirement while the Eighth goes no further than adopting $S-E-G$ 's contention that refusal to join a gang does not constitute a political opinion. The Seventh Circuit remains the only circuit to have outright rejected $S-E-G$-'s new social group requirements.

\section{A. Circuits Applying S-E-G's Social Visibility to Gang Cases}

Constrained by Chevron deference, the Sixth, Ninth and Eleventh Circuits have all adopted $S-E-G$-'s use of social visibility as a requirement for social group membership. Despite its lack of jurisdiction to review the merits of the petitioner's asylum claim because he failed to exhaust his administrative remedies, the Sixth Circuit appears to cite $S-E-G$ - with approval in Herrera-Flores v. Mukasey. ${ }^{78}$ The petitioner in Herrera-Flores was a 28 -year-old Salvadoran man who claimed that gang members trying to recruit him would kill him if he returned to El Salvador. ${ }^{79}$ Judge Griffin lamented that the respondent cited no authority to support his proposed social group of "young Salvadoran males who fear gang recruitment or who choose not to join gangs." Judge Griffin cited $S-E-G$-'s rejection of the social group for failing the social visibility test. Thus, the Sixth Circuit adopts a blanket approach to determinations on the validity of a social group, finding that where a group is not socially visible in one case, it cannot be in another.

In Gomez-Benitez v. Mukasey, the Eleventh Circuit found that Honduran schoolboys who conscientiously refuse to join gangs also did not constitute a social group. ${ }^{81}$ The Gomez-Benitez court cites both $S-E-G$ - and $E-A-G$ - with approval to support the lack of social visibility for the proposed social group. ${ }^{82}$ The Court focused on the lack of particularity, finding that "Gomez's purported group is so broad and persecution-defined that recognizing it under the Immigration and Nationality Act would permit the 'particular social group' persecution basis to become a 'catch all' ground for all persons alleging persecution in Honduras who cannot establish refugee status under any of the other recognized grounds."

77. See, e.g., Galindo-Torres v. Holder, 348 Fed. Appx. 814 (3d Cir. 2009); ContrerasMartinez v. Holder, 346 Fed. Appx. 956 (4th Cir. 2009); Mendoza-Marquez v. Holder, 345 Fed. Appx. 31 (5th Cir. Aug. 24, 2009); Orellana-Monson v. Holder, 332 Fed. Appx. 202 (5th Cir. 2009); Cruz-Alvarez v. Holder, 320 Fed. Appx. 273, 274 (5th Cir. 2009).

78. Herrera-Flores v. Mukasey, 297 Fed. Appx. 389, 29-30 (6th Cir. 2008).

79. Id. at 2 .

80. Id. at 29 .

81. Gomez-Benitez v. Mukasey, 295 Fed. Appx. 324, I (1 I th Cir. 2008).

82. Id. at 326. In a subsequent and unpublished decision, the Eleventh Circuit rejected a Salvadoran family's asylum claim based on the rape and harassment of a daughter who refused to join the Maras, for failure to meet the social visibility test. See De Vasquez v. United States AG, 345 Fed. Appx. 441 ( 11 th Cir. 2009).

83. Id. 
Eleventh Circuit decision clearly articulates the rationale likely underlying many of the gang-related asylum cases: the "floodgates" argument, which arises from fears that once asylum is open to those fleeing gang persecution little remains to stop any victim of violence or crime from seeking asylum successfully. This fear was also asserted in reference to gender-related persecution claims. ${ }^{84}$ Fears that the United States would be flooded with women fleeing Female Genital Cutting have not, however, materialized. ${ }^{85}$ Furthermore, the size of a persecuted group is irrelevant to whether asylum should be granted. The number of political dissidents fleeing communist regimes during the Cold War was large, yet these dissidents were granted asylum. Youth fleeing gang persecution are exactly the kind of group that the social group ground was intended to address - to give refugee status to those suffering persecution on account of their membership in a particular social group not otherwise covered by race, religion, nationality, or political opinion. ${ }^{86}$

The Ninth Circuit ${ }^{87}$ first embraced Matter of $S-E-G-$ 's reasoning in SantosLemus v. Mukasey, where Judge Wallace, writing for the panel, affirmed the BIA's

84. See Karen Musalo, Protecting Victims of Gendered Persecution: Fear of Floodgates, or call TO (Principled) Action? 14 Va. J. Soc. Pol'y \& L. 119 (2007). Musalo advocates for a principled approach, crafting policy responses and strategies to address the root causes of gendered persecution.

85. Id. at 132-34 (explaining why the fear of floodgates with respect to gendered persecution claims is unwarranted. Like women, children fleeing gang persecution often lack the resources to flee the persecution they experience and are dependent on their family members located in the country of origin for daily support).

86. The term "membership in a particular social group" first appeared in U.S. law, in the 1980 Refugee Act, which was specifically drafted to bring the U.S. into compliance with its treaty obligations under the 1967 Protocol to the International Refugee Convention. See, S.Rep. No. 96-256, 96th Congress, 1st Session (1979), Report on the Refugee Act of 1979 at 1, 4 ("the new definition will bring United States law into conformity with our international treaty obligations under the United Nations Protocol Relating to the Status of Refugees which the United States ratified in November 1968, and the United Nations Convention Relating to the Status of Refugees which is incorporated by reference into the United States law through the Protocol."). In short, there are two historical approaches to the development of the social group category in international law. The first considers the 1951 Refugee Convention's terminology as arising from the International Refugee Organization's 1946 Constitution. That Constitution included protection of groups such as "children who are war orphans or whose parents have disappeared, and who are outside their country of origin," Spanish Republicans, and victims of Nazi or Fascist regimes. See Constitution of the International Refugee Organization, and Agreement on Interim Measures to be Taken in Respect of Refugees and Displaced Persons, Annex I, Sixty-Fifth Plenary Meeting, December 14, 1946. Interestingly enough, any of the aforementioned social groups would easily meet the Acosta standard's immutable characteristic test in that they all share the immutable experiences of their social groups. However, aside from the Nazi victims who were tattooed with prisoner identification numbers, many of these refugees would not meet the social visibility standard as established by Matter of $C-A$ - . The second approach looks to the negotiating history of the 1951 Refugee Convention as it unfolded during the conference of plenipotentiaries. There, Swedish delegate Sture Petren requested the addition of: "a reference to persons who might be persecuted owing to their membership of a particular social group. [As] [s]uch cases existed, and it would be as well to mention them explicitly." 26 November 1951 Conference of Plenipotentiaries on the Status of Refugees and Stateless Persons: Summary Record of the Nineteenth Meeting Doc Symbol: A/CONF.2/SR.19. Other commentators agreed with the need for a gapfiller, mentioning that "experience ha[s] shown that certain refugees ha[ve] been persecuted because they belonged to particular social groups. The draft convention makes no provision for such cases, and one designated to cover them should be accordingly included." See Maryellen Fullerton, A Comparative Look at Refugee Status Based on Persecution Due to Membership in a Particular Social Group, 26 Cornell Int'l L. J. 508 (1993). The amendment including a particular social group in the refugee definition was adopted by 14 votes to none, with 8 abstentions. Conference of Plenipotentiaries, A/CONF.2/SR.19.

87. The Ninth and Second Circuits see the highest volume of immigration cases in the U.S. and thus are considered leaders in this area of the law. The Ninth Circuit has thus produced more cases in this specific subject area since $S-E-G$ was issued in July 2008 
denial of asylum to a Salvadoran man fleeing gang persecution. ${ }^{88}$ Like the Mira siblings in $S-E-G$-, the petitioner in Santos-Lemus had proposed two social groups the first based on family, the second based on his resistance to gangs. The BIA found that the presence of Santos-Lemus's mother in El Salvador undermined his family-as-a-social-group claim. Reading social visibility as a requirement, the BIA found Santos-Lemus's second asserted social group to be undermined by the lack of social visibility. On political opinion, the BIA held that "resistance to gangs or "antigang opinions' is not a 'protected political opinion.", 89

The Ninth Circuit found that Santos-Lemus was "victimized for economic and personal reasons" and that "[t]hese motivations do not constitute persecution on account of political opinion." system. ${ }^{91}$ Critics, however, argue that the BIA failed to "analyze Mr. SantosLemus's reasons for opposing the gangs to determine whether his opinion could be considered "political." ${ }_{2}$ Further, there must be an individualized analysis on political opinion and that the Santos-Lemus court affirmed the BIA's "per se ruling that anti-gang beliefs can never be political." rule "conflicts with well-established precedent that the determination of what constitutes political opinion must be made on a case by case basis."

The Ninth Circuit, like the BIA in Matter of $S-E-G$-, inconsistently discussed social visibility as both a factor and a requirement in the social group definition. Initially, the Santos-Lemus court explained that it considers "certain factors," including particularity and social visibility, citing Matter of $A-M-E-\& J-G-$ $U-.{ }^{95}$ Later, the court stated that although Matter of $S-E-G$ - was not "binding on [it]," the Ninth Circuit had "already adopted the Board's particularity and social visibility requirements in determining whether a purported association or characteristic creates a particular social group." Finally, the Santos-Lemus court adopted social visibility as a requirement, holding that "Santos-Lemus's group fails to qualify as a particular social group because it lacks social visibility.",7?

Social visibility determinations must be based on the facts and context of a particular country. ${ }^{98}$ The Santos-Lemus court erred in finding $S-E-G$-dispositive on

88. Santos-Lemus v. Mukasey, 542 F.3d 738 (9th Cir. 2008). One other decision, BarahonaSalguero v. Holder, 2009 U.S. App. LEXIS 4369 (9th Cir. 2009) cites Santos-Lemus for the standard of review of the BIA decision. Another decision cites Santos-Lemus in denying the Salvadoran petitioner relief under the Convention Against Torture. See Enriquez-Menjivar v. Holder, 313 Fed. Appx. 967 (9th Cir. 2009).

89. Id. at 746 .

90. Id. at 747 .

91. Id.

92. CGRS Santos-Lemus amicus brief, supra note 38.

93. Id. at 4 .

94. Id. at 5 (citing Caceres-Cuadras v. I.N.S., 912 F.2d 468 (9th Cir. 1990)).

95. Santos-Lemus, 542 F.3d 738 at 744.

96. Id. at 745 (emphasis added). But note that the Ninth Circuit has since held that "[b]ecause the BIA's determination that a certain group is or is not a 'particular social group' is part of its effort to give an ambiguous statutory term concrete meaning, we hold that Chevron deference is due." See RamosLopez v. Holder, 563 F.3d 855, 879 (9th Cir. 2009).

97. $I d$. at 746 .

98. CGRS Santos-Lemus amicus brief, supra note 38 at 7 (citing In re $A-M-E$ - and J-G-U"Whether a proposed group has a shared characteristic with the requisite 'social visibility" must be considered in the context of the country of concern and the persecution feared.") 
the factual issue of whether "young men in El Salvador who oppose gang violence" have social visibility. ${ }^{99}$ This is impermissible according to a 1969 Ninth Circuit case, Kovac, which found that an individual was "entitled to a determination" based on the facts of his own case, and "not of others."

The lawyers for Santos-Lemus filed a petition for rehearing en banc, supported by amicus briefs. The Center for Gender and Refugee Studies' (CGRS) amicus brief noted that the Santos-Lemus court's cites Arteaga v. Mukasey, ${ }^{101}$ which rejected petitioner's proposed social group of tattooed former gang members, because granting relief to "violent street gangs who assault people and who traffic in drugs and commit theft" would be contrary to the purposes of asylum law. ${ }^{102}$ CGRS argued that Arteaga does not support Santos-Lemus, but rather highlights the underlying policy rationales in defining a social group. CGRS explained that the Arteaga court "[did] not apply the criteria of social visibility as a straitjacket which prevents it from applying the law in a manner inconsistent with its understanding of congressional intent." ${ }^{103}$ Arguably, it would similarly violate congressional intent to exclude "young men of conscience, who motivated by their moral and religious beliefs, reject gang membership."

The Santos-Lemus court decided the particularity issue by referencing $S-E$ $G$ - and other "relevant [Ninth Circuit] case law," holding that the social group of "young men in El Salvador resisting gang violence is too loosely defined to meet the requirement for particularity." 105 The court also found that the "harassment appears to have been part of general criminality and civil unrest."106 The court found "nothing to distinguish [Santos-Lemus] from the rest of the population or cause others who oppose gang violence to recognize him as a member of their 'group.",107

The Ninth Circuit denied the petition for rehearing and rehearing en banc in Santos-Lemus without opinion in February 2009. ${ }^{108}$ Therefore, Santos-Lemus, and by implication, Matter of $S-E-G-$, are firmly entrenched in Ninth Circuit jurisprudence. In the year following the Ninth Circuit's Santos-Lemus decision, the court cited it on at least forty-four occasions. ${ }^{109}$

99. Id. at 8 . In a similar vein, the Court recently held that $S-E-G$-'s determination could preclude a claim from a Honduran youth who refused recruitment because the "same gang [wa]s at issue albeit in different countries." Ramos-Lopez v. Holder, 563 F.3d 855, 860 (9th Cir. 2009). The Court further extended this reasoning to an applicant from neighboring Guatemala and to other "rival" gangs in Barrios v. Holder, 567 F.3d 451, 456 (9th Cir. 2009) ("The BIA's reasoning in Matter of $S-E$ - $G$ - is no less applicable to the Mara 13 (or an equivalent gang) in Guatemala. Because Ramos claims persecution by either the Mara 13 or a rival Central American gang, our decision in Ramos-Lopez controls.")

100. Brief for Amicus Curiae, Santos-Lemus, 542 F.3d 738 (No. 07-70604) (citing Kovac v. INS, 407 F.2d 102 (9th Cir. 1969)).

101. Arteaga v. Mukasey, 511 F.3d 940 (9th Cir. 2007).

102. Id. at 945 .

103. CGRS Santos-Lemus Brief for Amicus Curiae, supra note 38, at 10

104. Id.

105. Santos-Lemus, 542 F.3d at 745-46.

106. Id. at 746 .

107. Id.

108. Although the denial of rehearing en banc is not available online, the authors learned that the petition for rehearing en banc had been denied from the Center for Gender and Refugee Studies, who had submitted an amicus brief in the case.

109. Many of these decisions have cited Santos-Lemus for propositions unrelated to social visibility and social group and many of the decisions are unpublished memorandum dispositions. For example, at least six cases have cited Santos-Lemus, holding that an applicant's fear of future persecution 
Several cases have cited Santos-Lemus's holding that social groups involving gangs are not valid social groups for asylum purposes. ${ }^{110}$ In Ramos-Lopez v. Holder, a case involving a seventeen-year-old Honduran who fled after refusing recruitment by the MS-13, the Ninth Circuit revisited social visibility. In that case, Judge Tashima classified threats and harassment faced by individuals refusing gang recruitment as a "sad part of the 'general criminality and civil unrest' perpetrated and perpetuated by the MS-13 in Central America" and found no evidence that those recruited by gangs were socially visible. ${ }^{111}$ Judge Tashima used Ramos-Lopez's own testimony that Honduran police take indiscriminate action against "children who are not in gangs in their efforts to curb gang activity" to further highlight the absence of social visibility in his purported social group. ${ }^{112}$ In fact, Tashima found that "while MS-13 members may be able to identify those who have resisted recruitment, it is not because the group, as a group, is visible; rather, MS-13 members appear to keep tabs on individuals who have refused to join. ${ }^{113}$ Judge Tashima's comment illuminates one of the strongest criticisms of the use of social visibility as a requirement - why should society's perception of an individual inhibit protection, when it was the persecutor's own perception of that individual which motivated the harm in the first place and will lead to any reasonable fear of future harm?

Much like the Ninth Circuit's treatment of social visibility and particularity, the Second, Fourth and Fifth Circuits have all issued decisions adopting $S$ - $E$ - $G$-'s "requirements" in gang-related cases, but none have chosen to publish their decisions. ${ }^{14}$ It is as yet unclear what guides the decision to issue unpublished non-

based on membership in a particular social group of "family" is undermined by similarly situated family members remaining in the country of origin without harm. See Aviles-Chavez v. Holder, 317 Fed. Appx. 678, 679 (9th Cir. 2009) (denying a petition for review because the "questions raised for review are so insubstantial as not to require further argument" because the court had previously rejected the argument that resistance to joining gangs in El Salvador constitutes political opinion); Rojas-Ayala v. Holder, 316 Fed. Appx. 621, 622 (9th Cir. 2009) (citing Santos-Lemus to hold that "a general aversion to gangs does not constitute a political opinion for asylum purposes," and also citing to the Santos-Lemus holding on particularity as a requirement for social group cases). At least two cases have cited Santos-Lemus' holding on political opinion with approval. See Aviles-Chavez, 317 Fed. Appx. at 678-79 (denying a petition for review because the "questions raised for review are so insubstantial as not to require further argument" because the court had previously rejected the argument that resistance to joining gangs in El Salvador constitutes political opinion.); Rojas-Ayala, 316 Fed. Appx. at 622 (citing Santos-Lemus to hold that "a general aversion to gangs does not constitute a political opinion for asylum purposes," and also citing to the Santos-Lemus holding on particularity as a requirement for social group cases).

110. See Chavez-Arevalo v. Mukasey, 308 Fed. Appx. 126, 127 (9th Cir. 2008) (denying petition for review because "victimization by criminal gang for personal or economic reasons is not persecution on account of protected ground"); Garcia v. Mukasey, 300 Fed. Appx. 530, 531(9th Cir. 2008) (denying petition for review of Salvadoran woman fleeing gang persecution and citing Santos-Lemus holding that "[young men] in El Salvador resisting gang violence" is not a particular social group for purposes of asylum" with approval).

111. Ramos-Lopez v. Holder, 563 F.3d 855, 862 (9th Cir. 2009).

112. Id.

113. Id.

114. See, e.g., Vasquez v. Holder, 343 Fed. Appx. 681, 683 (2d Cir. 2009) ("We defer to the agency's interpretation of the statute as announced in Matter of $S-E-G$ - and Matter of $E-A-G-$. Because those decisions are virtually indistinguishable from the instant case, we conclude that Vasquez's social group claim must fail."); Contreras-Martinez v. Holder, 346 Fed. Appx. 956, 958-59 (4th Cir. 2009) (finding 'in addition to 'immutability,' the Board requires that a particular social group have: '(1) social visibility, meaning that members possess characteristics . . . visible and recognizable by others in the native country, ... (2) be defined with sufficient particularity to avoid indeterminacy, . . . and (3) not be defined exclusively by the fact that its members have been targeted for persecution[.]," (citing Scatambuli v. Holder, 558 F.3d 53, 59 (1 st Cir. 2009))); Mendoza-Marquez v. Holder, 345 Fed. Appx. 31, 32 (5th Cir. 
precedent memorandum dispositions.

\section{B. The Eighth Circuit's Application of S-E-G-to Political Opinion}

In Marroquin-Ochoma, the Eight Circuit considered whether a bank worker who received telephonic and written threats against her life if she did not give money to or join the Mara Salvatrucha in Guatemala was persecuted on account of her social group and/or anti-gang political opinion. ${ }^{115}$ Eighth Circuit Judge Melloy concluded that mere refusal to join a gang does not compel a finding that subsequent threats were on account of an imputed political opinion, stating that "[o]pposition to a gang such as Mara Salvatrucha may have a political dimension, but refusal to join the gang is not necessarily politically motivated." 116 Judge Melloy reasoned that:

[A]t most, evidence that the gang is politically minded could be considered evidence that the gang members would be somewhat more likely to attribute political opinions to resisters. But even were we to conclude that Mara Salvatrucha does in fact operate 'in a political framework,' a 'generalized 'political' motive underlying the [gang's] forced recruitment [would be] inadequate to establish ... the proposition that' the gang believes resistance to those recruitment efforts is based on an anti-gang political opinion."

Encountering a "dearth of evidence in the record supporting a contrary conclusion," Judge Melloy used Matter of $S-E-G$ - to find that asylum cannot be granted on the grounds of political opinion where there is "no evidence in the record that the respondents were politically active or made any anti-gang political statements." 118

The Eighth Circuit's extensive treatment of Marroquin-Ochoma's claimed political opinion and failure to address her social group claim may indicate that the Circuit is not ready to adopt either of $S-E-G$-'s social group requirements.

\section{Circuits Applying S-E-G'S Social Visibility and Particularity Factors to Non-Gang Cases}

Several circuit courts have cited to $S-E-G$ - in cases not involving gang persecution. In one particularly interesting case, Ninth Circuit Judge Kleinfeld found that a Bulgarian petitioner's' friendship and support of Roma people did not amount to membership in a particular social group. ${ }^{11}$ Judge Kleinfeld used this case to

2009) (rejecting the social group of a family targeted by the Mara Salvatrucha in El Salvador and deferring to the BIA's "construction of a statute that it administers if the BIA's interpretation is reasonable.").

115. Marroquin-Ochoma v. Holder, 574 F.3d 574, 579 (8th Cir. 2009).

116. Id.

117. Id. at 578 .

118. Id.

119. Donchev v. Mukasey, 553 F.3d 1206 (9th Cir. 2009) ("As the BIA itself has recognized, the immutability requirement may be inapplicable in some circumstances. Wealth, even a trivial amount of it, targeted many "kulaks" and "landlords" for persecution in the Soviet Union and Communist China. According to the State Department's Profile on Bulgaria and other evidence in the record, people in Bulgaria who have Roma friends are not targeted for persecution as the kulaks and landlords were."). 
expound on the purposes of asylum and the dangers of expanding refugee status, arguing that "[o]verexpansion of refugee status to include amorphous social groups is unfair to other immigrants, because asylum jumps people to the head of the line of those seeking permission to live in the United States." ${ }^{20}$ While arguing that Chevron deference to the BIA's interpretation of membership in a particular social group was required, Kleinfeld found the social visibility analysis too "abstract" to be of real use. ${ }^{121}$ He stated that "when we are talking about membership in something other than a tribe or clan, this definition is not very helpful to deciding cases because the abstractness allows most disputes to be decided either way. What is 'fundamental' or 'innate' to one person may be a passing fancy to another." Ultimately, Judge Kleinfeld found that the applicant's friendship and advocacy on behalf of Bulgarian Roma persons was not a common immutable characteristic, as it was possible to change the characteristic:

Persons who have declined to join gangs, who have not served in the military, and who have declined to pay money to drug dealers, differ in obvious ways from the Tutsis in Rwanda, most obviously in that they have chosen a course of conduct that led others to harm them, whereas the Tutsis did not. Donchev's claim arises out of the choices he made in his friends. We cannot say that 'any reasonable fact finder would be compelled to conclude that Donchev's friendship with Roma individuals and the Roma people made him part of a particular social group. ${ }^{123}$

This analysis ignores a crucial part of the Acosta social group formulation: that the characteristic uniting a social group can either be one that is immutable, or one so fundamental to the identities or consciences of its members that they should not be required to change it. ${ }^{124}$ Judge B. Fletcher wrote a powerful dissent arguing that the traditional Acosta approach provides a clearer method of analysis. Judge Fletcher found Donchev's social group to be valid under Acosta, reasoning that Donchev's "friendships with, support, and defense of the Roma" was a common immutable characteristic so "fundamental to his individual identity and conscience [that] he should not be required to change it." 125

The First Circuit has accepted the relevance of the social visibility of a social group in the asylum context. ${ }^{126}$ In an opinion by Judge Lynch, the court

120. Id. at 1217. This desire to limit the availability of asylum is shared by Professor David Martin, now principal deputy general counsel for the Department of Homeland Security. See David Martin, "The Refugee Concept: On Definitions, Politics, and the Careful Use of Scarce Resources" in H. Adelman (ed.), Refugee Policy: Canada and the United States (1991) 30, reprinted in David Martin et al., Forced Migration Law and Policy 59-65 (Thomson/West 2007).

121. Id. at 1216 .

122. Id.

123. Id. at 1220. Such arguments are particularly disturbing as they shift the blame onto individuals who have chosen to exercise liberties that should be afforded every human being. Kleinfeld's contention that an individual's elected course of conduct does not warrant the same type of protection as persecution resulting from no individual election could easily be used to argue that those who "chose" to practice Judaism in Germany during the Holocaust elected their fate, a contention that any reasonable fact finder would be compelled to overturn.

124. Matter of Acosta, 19 I. \& N. Dec. 211 (BIA 1985).

125. Donchev, 553 F.3d at 1222-23.

126. Scatambuli v. Holder, 558 F.3d 53, 55-57 (1 st Cir. 2009). 
affirmed the BIA's denial of asylum to a Brazilian couple fearing persecution on account of their membership in a social group of "informants." 27 The First Circuit emphasized that this case did not "present the broad issue of whether informants who voluntarily provide information about illegality to law enforcement can ever be members of a particular social group." In this case, the First Circuit found that the BIA's finding that the particular informants involved lacked social visibility was based on substantial evidence. ${ }^{129}$ Judge Lynch also refused to "explore whether there is any tension between looking into the visibility of a particular social group and the requirement that members of a group share an immutable or fundamental characteristic." 130 The court's reluctance to address this issue suggests its awareness that the recent addition of social visibility may be in conflict with the traditional Acosta formulation. The court did, however, reject the petitioner's argument to "the extent petitioners are arguing the BIA is precluded from considering the visibility of a group." 131 Therefore, the First Circuit seems to consider social visibility as a factor, but not necessarily as a requirement.

In October 2008, the Second Circuit found that the proposed social group of "people who are targeted for gang violence because they are caught between rival criminal gangs but are not protected by police in China" lacked social visibility. ${ }^{132}$ Indeed, the court, in its summary order opinion, concluded that the petitioner had not shown that his proposed social group was "generally perceived as a distinct group by Chinese society." 133 The Second Circuit found the petitioner's failure to sufficiently establish the social visibility of his proposed social group "fatal to claims for asylum and withholding of removal." 134 The opinion also cites $S-E-G$ - for the proposition that "shared past experiences alone do not suffice to define a particular social group." 135 Although the facts of the case are not available in the appellate opinion, the court uses Matter of $S-E-G$ - and Matter of $E-A$ - $G$ - to summarily dispose of this claim. The opinion itself is only a few pages long and upholds a BIA affirmance without opinion on the original IJ decision. This unpublished decision suggets that the Second Circuit may treat social visibility as a requirement for social group cases.

The Tenth Circuit cited to $S-E-G$ - only for the holding that membership in a particular social group requires that the group have particular and well-defined boundaries. ${ }^{136}$ Judge Holmes held that the Nigerian respondent's proposed social group of "students who were forced to join a violent fraternity" was impermissibly circular and too broad. ${ }^{137}$ The Tenth Circuit's holding seems to rest on the more traditional common immutable characteristic approach of Acosta:

[W] can say unequivocally that a criminal gang/cult like the Black

Axe Confraternity does not qualify as a 'social group' under the

127. Id. at $56-58$.

128. Id. at 60 (emphasis added).

129. Id.

130. Id

131. Id.

132. Ming Jiang v. Mukasey, 296 Fed. Appx. 166, 168 (2d Cir. 2008).

133. Id. at 168 .

134. Id at $168-69$.

135. Id. at 168 .

136. Nkwonta v. Mukasey, 295 Fed. Appx. 279, 286 (10th Cir. 2008).

137. Id. at 285 . 
'immutable characteristic' test that this court has adopted for evaluating social-group persecution claims ... To state the obvious, membership in a criminal gang/cult is not something that a person either cannot change or should not be required to change.

The Court did not discuss social visibility, possibly indicating that the Tenth Circuit may not agree with the analysis suggested by $S-E-G-$.

\section{The Seventh Circuit's Rejection of $S-E-G$ - 's Social Visibility}

As the lone circuit thus far to reject $S-E-G$-'s social visibility requirement, the Seventh Circuit did so vehemently in Gatimi v. Holder. ${ }^{139}$ In an opinion authored by Judge Posner, the Court found that Kenyan defectors of the Mungiki ${ }^{140}$ constitute a particular social group. ${ }^{141}$ Attacking first the logic behind social visibility, Judge Posner stated:

it makes no sense; nor has the Board attempted, in this or any other case, to explain the reasoning behind the criterion of social visibility. Women who have not yet undergone female genital mutilation in tribes that practice it do not look different from anyone else. A homosexual in a homophobic society will pass as heterosexual. If you are a member of a group that has been targeted for assassination or torture or some other mode of persecution, you will take pains to avoid being socially visible; and to the extent that the members of the target group are successful in remaining invisible, they will not be 'seen' by other people in the society 'as a segment of the population." 142

Highlighting the absurdity of applying social visibility here, Posner comments: "The only way, on the Board's view, that the Mungiki defectors can qualify as members of a particular social group is by pinning a target to their backs with the legend 'I am a Mungiki defector.", "143 While mindful of the Supreme Court's determination that the BIA should be afforded deference and have an opportunity to opine on difficult social group issues in the first instance, ${ }^{144}$ Judge

138. Id

139. Gatimi v. Holder, 578 F.3d 611 (7th Cir. 2009). In the final stages of editing this article the Seventh Circuit issued a highly relevant decision, also authored by Judge Posner, rejecting social visibility once more and granting withholding to a Salvadoran former gang member who feared for his life or freedom based on his former gang membership. See Benitez Ramos v. Holder, 589 F.3d 426 (7th Cir. 2009).

140. The Mungiki sect is known for forcibly circumcising women and stripping women wearing trousers and miniskirts in public, among other practices. For a description on the Mungiki sect, see Gray Phombeah, Profile: Kenya's Secretive Mungiki Sect, BBC News Online, (Feb. 11, 2003), available at http://news.bbc.co.uk/2/hi/africa/2745421.stm.

141. Gatimi, 578 F.3d at 615-16 (referring to various social groups identified in Sepulveda v. Gonzales, 464 F.3d 770, 771-72 (7th Cir. 2006), the Court found the "Mungiki [to] constitute a group with as much coherence as children of the bourgeoisie, or of the aristocracy, had in the Soviet Union: breakaway factions that were relentlessly persecuted.").

142. Id. at 615; see also Benitez Ramos, 589 F.3d at 430-31.

143. Id. at 616.

144. Gonzales v. Thomas, 547 U.S. 183 (2006) (per curiam). 
Posner points out that in "regarding 'social visibility' as a criterion for determining 'particular social group,' the Board has been inconsistent rather than silent."145 Rejecting Chevron deference, Posner argues that

[w] hen an administrative agency's decisions are inconsistent, a court cannot pick one of the inconsistent lines and defer to that one, unless only one is within the scope of the agency's discretion to interpret the statutes it enforces or to make policy as Congress's delegate. Such picking and choosing would condone arbitrariness and usurp the agency's responsibilities.

Finally, the Seventh Circuit recognized that other circuit courts have "approved 'social visibility' as a criterion" in their particular social group determinations. ${ }^{147}$ While Judge Posner agreed with the results reached by his sister circuits (rejection of the formulated social groups) he concluded "[w]e just don't see what work "social visibility" does; the candidate groups flunked the basic "social group' test ... declared in cases like Lwin, Kasinga, and Acosta (where the test originated)." ${ }^{148}$ The authors are hopeful that the Seventh Circuit's decisions in Gatimi and Benitez Ramos will encourage other circuits to free themselves from the confines of the Chevron deference that they have been applying to $S$ - $E$ - $G$-'s social visibility and particularity requirements and return to the original Acosta test as Judge Posner and other Circuit Judges, including Judge B. Fletcher suggest.

\section{The Potential Negative IMPACT OF MATTER OF S-E-G- AND "SOCIAL VISIBILITY" ON CLAIMS INVOLVING GENDER AND SEXUAL ORIENTATION}

In the year since the BIA issued its decision in Matter of $S-E-G-$, the negative impact on social group cases involving gang-related persecution has been clear. Ten circuit courts have cited the case with approval. With the exception of the Seventh Circuit's grant of withholding in Benitez Ramos, Circuit courts have uniformly denied gang-related claims. ${ }^{149}$ Anecdotally, U.S. asylum practitioners generally believe that Immigration Judges are denying gang-related claims in light of $S-E-G$-. Advocates fear that $S-E-G$-'s elevation of social visibility from a factor in the determination of social group to a requirement poses a risk for other social group cases. In particular, $S-E-G$-' $s$ broad holdings may affect claims involving gender and sexual orientation.

145. Gatimi, 578 F.3d at 615-16 ("It has found groups to be 'particular social groups' without reference to social visibility, In re Kasinga, 21 I. \& N. Dec. at 365-66 (young women of a tribe that practices female genital mutilation but who have not been subjected to it); In re Toboso-Alfonso, 201 . \& N. Dec. 819, 822-23 (BIA 1990) (homosexuals); In re Fuentes, 19 I. \& N. Dec. at 662 (former members of the national police); cf. In re Acosta, 19 I. \& N. Dec. at 233-34 (refusing to classify socially invisible groups as particular social groups.).

146. Id. at 616 (internal citations omitted).

147. Id.

148. Id. (internal citations omitted).

150. See Marouf, supra n. 17; see also, Bah v. Mukasey, 529 F.3d 99, 110 n. 13 (2d Cir. June 11,2008 ) (where the BIA stated in the underlying case that it doubted "that young Bambara women who oppose arranged marriage have the kind of social visibility that would make them readily identifiable to those who would be inclined to persecute them"). 
Former Attorney General Michael Mukasey cited both Matter of $S-E-G$ and Matter of $E-A-G$ - in his recent action on the domestic violence case, Matter of $R$ $A-.{ }^{151}$ The AG flagged these two gang-related decisions, along with Matter of $A-M$ $E-\& J-G-U^{152}$ and Matter of $C-A-{ }^{153}$ as decisions relevant to Matter of $R-A$ - due to their elaboration on the terms "persecution," "on account of" and "particular social group." This is particularly troubling as women who oppose and suffer domestic violence are certainly no more "visible" than youth opposing gang persecution. Indeed, for years advocates have had to contend with the difficulties posed by the fact that most forms of persecution against women occur in the "private" realm.

Social visibility "raises the specter of the private/public distinction by requiring members of a particular social group to have a public face." ${ }^{155}$

Moreover, $S-E-G$-'s requirement of the social visibility of a social group may affect cases involving Female Genital Cutting (FGC), which have been established in U.S. asylum jurisprudence for the last thirteen years following Kasinga. ${ }^{156}$ The UNHCR letter to AG Holder of March 19, 2009, warned that a "typical Togolese tribal member [would not] inevitably be aware of young women who opposed female genital mutilation but had not been subjected to the practice."157 These cases could also be affected by $S-E-G$-'s holding on political opinion. If an anti-gang opinion and belief in the rule of law is not a political opinion, then antiFGC opinion and a belief in the sanctity of a woman's body seems similarly shaky.

Sexual orientation cases are similarly at risk. The UNHCR letter also warned that the "general population of Cuba would not automatically recognize homosexuals," so asylum seekers fleeing persecution on the basis of their sexual orientation, unless highly visible, may potentially have their claims rejected in light of $S-E-G-.{ }^{158}$ Often, social stigma forces gay and lesbian asylum seekers to hide their sexual orientation in their country of origin. ${ }^{159}$ Lesbians in particular may be affected by the requirement of social visibility as they "often remain completely invisible in the public sphere." ${ }^{, 160}$ Requiring a level of social visibility may preclude

151. Matter of R-A-, Interim Decision. 24 I. \& N. Dec. 629 (Sept. 25 2008). In re R-A-, 22 I. \& N. Dec. 906 (2001) worked its way through the asylum system since 1996. Rodi Alvarado, the applicant, made several failed appeals to the Guatemalan police for protection from her husband's extreme domestic abuse. Eventually, she fled to the US and applied for asylum. Her case was pending for more than ten years. Most recently, Attorney General Mukasey certified $R-A$ - and ordered the BIA to reconsider the case, removing the requirement that the BIA await the issuance of proposed regulations. The BIA remanded to the $\mathrm{IJ}$, who requested briefing on the issue of social visibility. DHS responded that it did not oppose a grant of asylum. Ms. Alvarado was recently granted asylum by the IJ. See generally Ctr. for Gender \& Refugee Studies, Documents and Information of Rodi Alvarado's Claim for Asylum in the U.S., http://cgrs.uchastings.edu/campaigns/alvarado.php (last visited Apr. 15 2010).

152. In re $A-M-E-\& J-G-U-, 24$ I. \& N. Dec. at 70-77.

153. In re C-A-, 23 I. \& N. Dec. at $951,953,955-56,958-60$.

154. See Marouf, supra n. 17 at $94-99$ (discussing how social visibility affects domestic violence, family based, and human trafficking claims).

155. Id.

156. Matter of Kasinga, 21 I. \& N. Dec. 357.

157. UNHCR Letter, supra n. 71 at 4.

158. Id. (citing Toboso-Alfonso, 20 I. \& N. Dec. 819 (BIA 1990)).

159. See Marouf, supra n. 17 at 79; See also Sharalyn Jordan, Un/Convention(al) Refugees: Accounts of Escape and Exile from Homophobic and Transphobic Persecution. Presentation at Centre for Refugee Studies Annual Student Conference, York University, Canada (April 16, 2009) (on file with author).

160. See Marouf, supra n. 17 at 84. 
all homosexual asylum seekers but "effeminate men or butch lesbians" from being granted asylum "because they are the only ones perceived as homosexual by their societies."

Clear practical difficulties arise in applying social visibility as a standard. Social perception depends on several factors operating at a given time or in a certain context. ${ }^{162}$ The concept of social visibility "ignores the ways in which power relations shape social identities and influence the relative visibility or invisibility of various groups." ${ }^{\prime 63}$ Indeed, some societies purposely ignore social groups, denying their existence and thus, visibility. ${ }^{164}$ Because social visibility is often not a black or white issue, ${ }^{165}$ making it a requirement for a valid social group will lead to inconsistent and unreliable results. It will also be very difficult for adjudicators to derive "social visibility" from traditional types of documentary evidence (the kind ordinarily submitted in asylum claims). ${ }^{166}$ Generally, little information exists as to how a particular society perceives or does not perceive a particular group. Thus, the only way to really tell that a group had been "perceived" as such in the past would be where that group has been singled out for persecution. Thus, social visibility could create a quasi-requirement of past persecution.

Overall, $S-E$ - $G$-'s approach to social visibility could pose an obstacle for gender and other social group cases. The fact that gender cases have not yet been so affected suggests that social visibility is a tool adjudicators employ to avoid granting asylum in politically unpopular cases. Indeed, whether or not asylum is granted largely depends on the adjudicator and location in which the applicant applies, with certain jurisdictions manifesting clear preference for applicants from certain countries of origin. ${ }^{167}$ Alternatively, perhaps it is just too soon to tell how social visibility will affect these groups.

\section{LeSSONS FROM CANADA: CANAdian JuRISPRUdENCE IN CENTRAL AMERICAN GANG CASES.}

As the other North American asylum-receiving country, Canada's jurisprudence may shed light on Central American gang-related asylum claims. A review of eighteen gang cases issued between 2005 and 2009 by both the Immigration and Refugee Board (IRB) of Canada, and the Federal Court, reveal the following three themes:

1. Most IRB and Federal Court cases found that state protection against gangs in the country of origin (usually El Salvador ${ }^{169}$ or Honduras ${ }^{170}$ ) was adequate

161. Id. at 87 .

162. Id. at $73-74$.

163. Id. at 105 .

164. Marouf gives the example of homosexuals in Iran, but other groups are possible to imagine - for example, Central American governments often deny that there is a gang problem, thus denying visibility and the existence of gang-related persecution victims.

165. Id. at 83 .

166. Id. at 76-78.

167. J. Ramji-Nogales et al., Refigee Roulette: Disparities in Asylum Adjudication, 60 STAN. L. REV. 2 (2007).

168. The pending Matter of $R-A$-decision should give us an indication of how the BIA will address gender cases using the notion of social visibility.

169. Mejia v. Canada (Minister of Citizenship and Immigration), [2006] F.C. 12 (Can.) 
and that the individual applicant lacked an individualized risk of harm, ${ }^{171}$ but risked only more generalized violence affecting the entire population in the country of origin. In several cases the courts found that efforts by Central American governments to address the gang problem demonstrated state willingness and ability to protect individual applicants fleeing gang violence.'

2. The Canadian courts held that an applicant found to be a member of the Maras was inadmissible under Section 37(1)(a) of the Immigration and Refugee Protection Act, S.C. 2001. ${ }^{173}$ No exceptions were made for child members of the Maras. For example, in one case, the IRB held that a thirteen-year-old made a conscious decision to join a gang and was thus inadmissible under Section $37(1)(a){ }^{174}$

3. A few Canadian cases provide some hope to those fleeing gang-related persecution in Central America. These cases are discussed below.

In 2006, Judge Gibson decided the case of a twenty-three year old Guatemalan man fleeing persecution at the hands of the Mara 18. ${ }^{175}$ Judge Gibson determined that the IRB had neither properly considered the applicant's claim nor provided sufficient rationale for its denial. The decision was set aside in light of evidence supporting the applicant's assertions regarding country conditions in Guatemala.

Justice Shore seems to be an emerging champion for asylum applicants fleeing gang related violence in Central America. ${ }^{176}$ In 2006, Justice Shore overturned an IRB ruling based on a lack of state protection from gangs in

(denying section 97 protection as the applicant was the subject of a generalized problem in his country and the applicant had not submitted clear and convincing evidence that state protection was unavailable); Panigua v. Canada (Minister of Citizenship and Immigration), [2008] F.C. 1085 (Can.) (finding that although the applicant faced an individualized risk of harm, state protection was available); Medina $v$. Canada (Minister of Citizenship and Immigration), [2003] F.C. 1465 (Can.) (affirming IRB holding that state protection was available in El Salvador); Velasquez $\mathrm{v}$. Canada (Minister of Citizenship and Immigration), [2009] F.C. 109 (Can.) (deferring to IRB's findings on availability of state protection and an internal flight alternative and holding that failure to seek state protection due to fear of reprisal by the Maras is insufficient).

170. Acosta v. Canada (The Minister of Citizenship and Immigration), [2009] F.C. 213 (Can.) (approving IRB finding that the applicant had only a generalized, rather than personal, risk of harm).

171. 2006 CanLII 62248 (I.R.B.)

172. 2006 CanLII 61231 (I.R.B.) (holding that the Honduran woman who suffered gang rape by her former husband and Mara Salvatrucha members did not seek state protection, that police corruption in Honduras does not affect the applicant's claim, and that the crackdown on gangs shows government willingness to act); 2007 CanLII 70660 (I.R.B) (finding El Salvador's Super Firm Hand plan and other steps demonstrate the availability of state protection and that applicant, living in a democracy, should have sought state protection.); 2006 CanLII 61808 (I.R.B.) (holding that the Salvadoran government is willing and able to offer protection to its nationals and is making serious efforts to control the gang; further, applicant did not show that her efforts to seek protection were adequate.); 2005 CanLII 60088 (I.R.B.) (finding that El Salvador offers sufficient state protection and that the applicant's claim was not credible).

173. Mendoza v. Canada (The Minister of Public Safety and Emergency Preparedness), [2007] F.C. 934 (Can.).

174. 2007 CanLII 47735 (I.R.B.) (May 22 2007) ("(E)ven at age 14 [sic], [applicant] had the knowledge and mental capacity to understand that he was joining a gang and that there were obligations and consequences that would flow."). F.C. 404 (Can.)

175. Luis Alejandro Lemus Ortiz v. Canada (Minister of Citizenship and Immigration), [2006]

176. But see Justice Shore's decision in Ayala v. Canada (Minister of Citizenship and Immigration), 2007 F.C. 690 (Can.) (affirming the IRB's findings on state protection and credibility in the case of two Salvadoran applicants fleeing gang violence). 
Honduras. ${ }^{177}$ The IRB had failed to consider documentary evidence "contradicting the supposed availability and effectiveness of State protection for [Honduran] citizens having to deal with gang-related problems."

On the issue of a generalized risk versus an individual risk of gang persecution, Justice de Montigny remanded a Refugee Protection Division decision involving a Salvadoran fleeing the MS-13, explaining:

It cannot be accepted, by implication at least, that the applicant had been threatened by a well-organized gang that was terrorizing the entire country, according to the documentary evidence, and in the same breath surmise that this same applicant would not be exposed to a personal risk if he were to return to El Salvador. It could very well be that the Mara Salvatruchas recruit from the general population; the fact remains that Mr. Pineda, if his testimony is to be believed, had been specifically targeted and was subjected to repeated threats and attacks. On that basis, he was subjected to a greater risk than the risk faced by the population in general. ${ }^{179}$

The Refugee Protection Division had rested their conclusion that the applicant faced no individualized risk solely on his assertion that the gang "recruited across the country and targeted all levels of society." 180

In 2008, Justice Mosley remanded the case of a Salvadoran orphan recruited by the Mara $18,{ }^{181}$ in light of the Refugee Protection Division panel's failure to consider reasonableness in their analysis of the applicant's internal flight alternative. ${ }^{182}$ More recently, in Sanchez v. Minister of Citizenship and Immigration, the Court granted a stay of removal in the case of a Salvadoran youth persecuted by MS-13. ${ }^{183}$ Justice Shore found "significant new information that conditions [in El Salvador] had worsened and that the state's 'serious efforts' to control gangs had failed. The Super Mano dura (super heavy hand) was discredited as counterproductive, and fizzled out by the end of 2007." 184

Canadian jurisprudence on gang-related asylum claims includes no discussion of social group or social visibility. Instead, the cases focus on individualized risk and whether the country of origin is unwilling or unable to offer protection. It is possible, then, given the lack of focus on social group, that the Mira siblings in $S-E-G$ - might have been granted asylum in Canada. Assuming they could

177. Fabio Yovanny Gonzalez Membreno v. Canada (Minister of Citizenship and Immigration), [2006] F.C. 439 (Can.).

178. Id. at $\uparrow 18$.

179. Pineda v. Canada (Minister of Citizenship and Immigration), [2007] F.C. 365 at 1$] 15$.

180. Id. at 98 . F.C. 289 (Can.)

181. Wilber Orlando Cartagena v. Canada (Minister of Citizenship and Immigration), [2008]

182. Id. at $111-12$ ("The panel failed to thoroughly assess the reasonableness of the locations suggested as viable IFAs in the context of Mr. Cartagena's situation and vulnerable mind-set. A young man with little education and no prospects in any field other than menial labor is in a high risk category. His lack of family and fragile psychological state compound that risk.").

183. Balmore Alexander Ramos Sanchez v. Minister of Citizenship and Immigration and the Minister of Public Safety and Emergency Preparedness, [2009] F.C. 101 (Can.).

184. Id. at 944 . See discussion of Mano Dura, supra page 3. 
establish credibility, ${ }^{185}$ the siblings would have probably been able to demonstrate an individual risk of persecution. Finally, following the Sanchez case, the Canadian courts may have found the Salvadoran government unable to protect those fleeing gang persecution.

\section{CONCLUSION}

$S-E-G$ highlights the complexity of U.S. social group jurisprudence and a need for additional clarity. One way this clarity could be achieved is by amending the Refugee Act of 1980 to include a definition for social group. As Judge Fletcher suggests in her Donchev dissent, ${ }^{186}$ the $A$ costa formulation provides a clear approach to social group cases. Indeed, courts in other jurisdictions worldwide have adopted the Acosta standard. $^{187}$ Affirming the Acosta formulation for social group would ensure U.S. conformity with other asylum-receiving countries, such as Canada, New Zealand, and the United Kingdom, who have accepted that definition of social group. $^{188}$ In recent years, organizations working on behalf of asylum seekers have discussed such an amendment. Clearly, there are risks in amending the definition of social group. Defining social group may exclude future unanticipated groups of asylum seekers; nevertheless, careful drafting could avoid this outcome.

The current AG could intervene as former AG Reno did in the case of Matter of $R-A$ - and order the BIA to revisit $S-E-G$ - while simultaneously encouraging the Department of Justice to issue regulations on the subject of membership in a particular social group. ${ }^{189}$ Such action is particularly appropriate in light of the aforementioned inconsistencies in the BIA's interpretation of membership in a particular social group and the wide range of Circuit court treatment of the issue. The clearest solution would be the aforementioned return to the Acosta formulation of social group membership.

Short of legislative change, new regulations or a favorable review of $S-E-G$, how can advocates best represent victims of gang-related persecution? How can judges best approach these cases? Perhaps these cases provide an opportunity for truly creative lawyering. ${ }^{190}$ As Mathew Lister explains, these cases do fall within the traditional asylum paradigm, and "with creative formulation and use of evidence,

185. In reviewing Canadian case law, establishing credibility seems to be an issue. In particular, although there is no deadline to apply for asylum (as in the United States, where a one-year deadline is imposed, Immigration and Nationality Act $\$ 208(a)(2)(B))$, Canadian adjudicators find that even a few months' delay in applying for asylum can undermine credibility. Participants in the 2009 Centre for Refugee Studies Annual Student Conference at York University in Toronto, Canada, agreed with this observation.

186. See Matter of Acosta, 19 I. \& N. Dec. 21

187. See UNHCR Letter, supra n. 71 at 4, n. 3.

188. Id. citing, for example, Canada v. Ward [1993] 2 S.C.R. 689 (Can.); Islam v. Secretary of State for the Home Department and R. v. Immigration Appeal Tribunal and Secretary of State for the Home Department, ex parte Shah, UK House of Lords, [1999] 2 W.L.F. 1015. Australia has adopted a social perception approach but takes into account immutable characteristics. See Applicant A v. Minister for Imm. \& Ethnic Affairs (1997) 190 C.L.R. 225 (Austl.)

189. See, e.g., Attomey General Reno's order overturning the decision in Matter of $R-A-$ (Jan. 19 2001), available through the Center for Gender \& Refugee Studies, supra n. 150.

190. Nathan Brooks, In Praise of Creativity: Gang-Based "Social Group" Claims in Asylum Cases, 56-FEB Fed. Law. 26 Feb. 2009. 
applicants in this emerging genre of asylum claims may experience more success."191 A lesson from the recent Canadian Sanchez case is to carefully focus on country conditions. Attempts to distinguish each gang-related persecution claim from the facts of $S-E-G$ - are also advisable. Where possible, advocates should show that the client's actions demonstrate a political opinion, imputed political opinion, or a religious belief. Most importantly, lawyers representing clients fleeing gang persecution should use available resources and other lawyers.

In the long term, improving the prospects for gang-related cases will require changing the public perception of those fleeing violence by gangs and criminal entities. Adjudicators and politicians alike need education on the nuances of the gang phenomenon so that conversations on the topic can move past a negative reaction to the word "gang." These nuances include distinguishing cases of forced recruitment of children from cases involving former gang members. Further, it is necessary for adjudicators to understand the range of socio-economic factors leading to gang membership.

When representing individual clients, advocates can also specifically attack the application of the concept of social visibility. First, as the Seventh Circuit has recognized in Gatimi and Benitez Ramos, courts should not defer to the BIA's concept of social visibility because it is an unexplained departure from established BIA precedent. ${ }^{193}$ Second, social visibility should not be a requirement for a particular social group as it is not considered for those claiming asylum based on other grounds such as race, religion, nationality, or political opinion. Finally, where evidence of perception is scant, application of a social visibility standard risks conflation of other required elements of a successful asylum claim. ${ }^{194}$ This is because where actual evidence of visibility is lacking, adjudicators will likely rely on evidence of harm (thereby conflating the persecution requirement), level of risk (thus conflating the "well-founded fear" requirement), or causal nexus (conflating the "on account of" requirement). ${ }^{195}$ The resulting inquiry becomes repetitive, as "social visibility" provides no further guidance to the adjudicator than do the traditional asylum elements.

Other legislative approaches to the situation may involve specifically addressing the gang-related persecution issue. ${ }^{196}$ An effective response to the plight of youth who resist gang recruitment must address the roots of the problem. To that end, the United States should focus on helping Central American nations address the

191. See Lister, supra n. 13 at 852 .

192. See, e.g., Capital Area Immigrants' Rights, Seeking Asylum from Gang-Based Violence: A Resource Manual (2007), www.ailf.org/lac/GangResourceManual.pdf; Washington Office on Latin America, Central American Gang-Related Asylum Guide (2008), www.wola.org; National Center for Immigrant and Refugee Children, Gang-related Asylum Resources, http://uscri.refugees.org/site/PageNav igator/Resource\%20Library/Asylum_Research_Gang_Related. The Center for Gender and Refugee Studies also provides technical assistance on social group cases and has developed expertise in this area after receiving numerous requests for assistance with gang-related persecution claims. See http://cgrs.uchastings.edu/assistance/index.php (last visited Apr. 15, 2010).

193. See discussion of Chevron deference, supra n. 55.

194. See Marouf, supra n. 17 at 104.

195. Id. at 76.

196. Funes, supra n. 7 at 332-37 (giving suggestions on U.S. law reform, including amending the definition of "aggravated felony" under the 1996 Immigration laws, entering into bilateral treaties on removal with specific Central American nations, and amending federal regulations to permit youths fleeing gang violence to be granted asylum). 
gang phenomenon. ${ }^{197}$ It seems that the Obama administration is attempting to do so, at least tangentially. The Department of Homeland Security Secretary increased in the number of U.S. law enforcement officers on the border, as part of the effort to help Mexico break up drug cartels. ${ }^{198}$ The administration has also pledged a renewed commitment to the Central American Fingerprint Exchange Initiative ${ }^{199}$ and the Transnational Anti-Gang Initiative. ${ }^{200}$ Despite the progress, more specific reform efforts - including rehabilitating former gang members, addressing gang violence, confronting police corruption, protecting youth, and empowering individuals to resist gang recruitment - are needed to ensure a long-term solution to the gang-persecution problem.

197. See Funes, supra n. 7 at 330-33. See also Musalo, supra n. 84 at 139-44 (noting U.S. influence in Guatemala due to its provision of economic assistance to Guatemala). This argument applies to other Central American countries receiving U.S. aid.

198. Fox News, U.S. to Redirect Resources to Stop Spillover Violence from Mexico (Mar. 24, 2009), http://www.foxnews.com/politics/2009/03/24/redirect-resources-stop-spillover-violence-mexico.

199. This initiative was developed to collect, store and integrate biometric data from El Salvador, Guatemala, Belize, Honduras, and the Mexican state of Chiapas. Id.

200. This initiative coordinates the sharing of gang intelligence between the U.S. and El Salvador, where the gang MS-13 originated. Id. For other recent U.S. efforts to address the gang problem, see Funes, supra n. 7 at $330-33$. 